\title{
Promoting the Growth of Chlorella vulgaris in Secondary Wastewater Treatment Effluent of Tofu Industry using Azospirillum sp
}

\author{
Wahyunanto A. Nugroho", Musthofa Lutfi ${ }^{\#}$, Bambang Susilo" \\ \# Department of Agricultural Engineering, Brawijaya University, Malang, East Java, Indonesia 65145 \\ E-mail:wahyunanto@ub.ac.id
}

\begin{abstract}
The objective of this research is to investigate the influence of growth promoting bacteria (GPB) Azospirillum sp on the growth of microalgae Chlorella $\mathrm{sp}$ in wastewater of tofu industry as a medium. To observe the influence, about $106 \mathrm{cells} / \mathrm{mL}$ of Chlorella sp was cultivated in $1 \mathrm{~L}$ of wastewater of tofu industry. The wastewater was an effluent of an aerobic treatment. Six different treatments were set regarding to the Azospirillum sp added to the medium. The glass was marked as A0 as no GPB inoculants added to the medium, and A2, A4, A6, A8 and A10 for $2 \mathrm{~mL}, 4 \mathrm{~mL}, 6 \mathrm{~mL}, 8 \mathrm{~mL}$ and $10 \mathrm{~mL}$ of GPB added to the medium respectively. The concentration of GPB inoculant was $108 \mathrm{cfu}$ per $\mathrm{mL}$. The result showed that the highest number of Chlorella population was achieved by addition of $6 \mathrm{~mL}$ GPB Azospirillum sp in the day 10, while the highest maximum growth rate was achieved by addition of $10 \mathrm{~mL}$ GPB Azospirillum sp to the medium.
\end{abstract}

Keywords - microalgae; growth promoting bacteria; wastewater

\section{INTRODUCTION}

Microalgae is a potential organism for bio-fuel feedstock production [1]. Lipid production by microalgae is in the range of $20 \%$ to $70 \%$ of its dry weight, depending on its species [2], [3], [4]. With an advanced culturing technique, the potential oil production of microalgae could reach $136,000 \mathrm{~L} / \mathrm{Ha} / \mathrm{y}$, which is much higher than oil production of terrestrial plants [5]. Another estimation, microalgae can produce about $120,000 \mathrm{~kg}$ biodiesel/ha year, or 20 times as much as the productivity of palm oil $(5,800 \mathrm{~kg}$ biodiesel / ha year) and 80 times higher than that of castor oil, which was about 1,500 kg biodiesel/ ha year [6]. Another benefit is this source of alternative energy does not compete with food crop for the land use.

Microalgae require an adequate nutrient in order to grow well. Carbon and inorganic nitrogen and phosphor are major element needed by the microalgae, besides some trace elements. To reduce the production cost due to the use of fertilizer, cultivation of microalgae in nutrient rich wastewater can be an alternative. Many microalgae have been reported to be feasible to grow well in wastewater [7], $[8,9]$. While most of the research was done in laboratory and pilot scale treatment $[10,11]$, a few of them have been practiced for industrial scale [12]. When it is cultured in the wastewater, microalgae have dual purposes, i.e. producing oil and other useful chemical substances, and also cleaning the wastewater by nutrient uptake, which is typically done in tertiary treatment, [13, 14, 15].

Wastewater of food industries contains complex organic materials, such as carbohydrates, protein and lipids, besides several microelements [16]. Tofu industries are widely spread in areas of Indonesia, and consumes a large amount of water per $\mathrm{kg}$ of raw material. The protein in its raw wastewater occupies about $60 \%$ of all solid fractions. Through amino acids fermentation in anaerobic treatment process, protein can be degraded into various organic compounds [17], which some of them can be used either for macronutrient or micronutrient for the autothrophic organism, such as microalgae. It is expected that this richnutrients wastewater is able to suppress the use of fertilizers that commonly practiced in the microalgae cultivation. A study by Nugroho et al. [18] shows that microalgae Chlorella vulgaris could grow well in nutrient-rich tofu industrial wastewater.

Microalgae have various productivities in wastewater, regarding to its growth and lipid production. So do its efficiency in nutrient uptake. Nutrient sources [1, 19], pH [20], temperature of medium [21], light intensity [22, 23], and size of the population [24] are several factors that affect microalgae productivity as well as its nutrient uptake efficiency. Studies of Chlorella $\mathrm{sp}$ cultivated in the municipal wastewater effluent revealed that the average growth rates of the microalgae were range from 0.343 day- 1 to 0.498 day $^{-1}$ [25]. Higher growth rate showed when 
microalgae were cultivated in more concentrated wastewater $[25,26]$.

To support the microalgae growth without any additional nutrient, Azospirillum sp as a growth promoting bacteria has been employed for the process [27]. Using alginate immobilization technique, about $25 \%$ increase for the growth rate was revealed when Chlorella vulgaris was coupled with Azospirillum sp, while less growth rate was occurred when Chlorella sorokiniana was cultivated instead of Chlorella vulgaris [28]. Indole Acetic Acid (IAA), a growth hormone secreted by Azospirillum sp is expected to be responsible for this significant increase of the microalgae growth. Azospirillum sp is a non-symbiotic nitrogen-fixing bacterium in terrestrial ecosystem. These bacteria lives freely in the soil and is employed as a soil fertilizer [29]. The growth hormone produced by this bacteria was about 285.51 mg / liter of total culture medium, and is likely able to improve the efficiency of fertilization [30]. In a separate study on the microalgae-bacteria interaction, an increase of the growth rate occurred when two species of green microalgae, Scenedesmus bicellularis and Chlorella sp, was cultured in laboratory-based experiment with two bacteria, Pseudomonas diminuta and P. vesiculari. was

A few has been reported about the use of non-native aquatic microorganism to support the growth of microalgae, and to further help purifying the water. Since it is water intensive process, tofu wastewater effluent contains less concentrated nutrient compared to wastewater from other food industries. It is expected that the addition of this bacterium could increase the growth rate of the bacterium during its culture. The objective of this research is to investigate how Azospirillum sp would promote the growth of microalgae Chlorella vulgaris in the tofu processing wastewater. Its performance in nutrient removal was also been investigated.

\section{MATERIALS AND METHOD}

\section{A. Culture and Growth Medium}

Chlorella vulgaris and Azospirillum sp was used for the microalgae and the growth promoting bacteria respectively. Chlorella vulgaris used in this experiment was a culture that was developed by Indonesian Bureau for Aquaculture Research (BBAP) Situbondo, East Java, Indonesia, while the bacterium was developed by the Laboratory of Soil Microbiology, Faculty of Agriculture, Brawijaya University, Indonesia.

The growth medium for the experiment was wastewater of tofu industry, which is located in Batu City, East Java, Indonesia. The wastewater was an effluent of an anaerobic treatment process. To avoid some gross fragment in the wastewater, a filtration screen was used prior to the sample storing in a cool box with maximum temperature of about $4^{\circ} \mathrm{C}$. As soon as it arrived in the laboratory, it was stored in under $4^{\circ} \mathrm{C}$ refrigerator and was used one day later. About 10 $\mathrm{ml}$ of the wastewater sample was analysed to observe its initial chemical compounds.

\section{B. Analysis of wastewater and microorganism}

The ammonium analysis was performed using standard nessler test using spectrophotometer Genesys 10uv with 425 $\mathrm{nm}$ of wavelength. Colorimetric nitrate analysis was done using Genesys 10uv with $410 \mathrm{~nm}$ of wavelength. The orthophosphate concentration was analysed using stannous chloride method and quantified using spectrophotometer Genesys 10uv with wavelength of $620 \mathrm{~nm}$. The medium temperature and $\mathrm{pH}$ was measured periodically to ensure that those two parameters were in the allowed condition for the microalgae and the bacterium to grow. The number of Chlorella vulgaris and Azospirilum sp were counted using haemocytometer under microscope. The microalgae growth rate was calculated using the equation below

$$
\mu=\frac{\ln X_{\text {max }}-\ln X_{0}}{T_{\text {max }}-T_{0}}
$$

The same formula was also used to calculate the growth rate of the Azospirillum sp.

\section{Experimental set up and statistical analysis}

The experiment was carried out in laboratory using $1000 \mathrm{~mL}$ Erlenmeyer glasses, and each glass contained about $500 \mathrm{~mL}$ of the medium. To give the aeration, an air pump was used with its air flow rate was 6 litre per min per bottle. A $40 \mathrm{~W}$ of fluorescence lamp was employed for 24 hours a day for the light source.

Each bioreactor was labelled differently, i.e. A0, A2, A4, A6, A8, and A10. All bioreactors was added with similar number of Chlorella vulgaris and mixed slowly. The targeted initial concentration of the Chlorella vulgaris in the medium was $10^{6}$ cells $/ \mathrm{ml}$. A different volume of Azospirillum sp inoculums was added to each reactor, except for reactor A0, which was acted as a control. The concentration of the Azospirillum sp inoculum was $10^{8}$ $\mathrm{cfu} / \mathrm{mL}$. Reactors A2, A4, A6, A8, and A10 were added with $2 \mathrm{ml}, 4 \mathrm{ml}, 6 \mathrm{ml}, 8 \mathrm{ml}$ and $10 \mathrm{ml}$ of the inoculum respectively. The number of microalgae was counted every day at $4 \mathrm{pm}$, while the number of bacteria was counted every four days. Each experiment was run for twelve days in triple replication.

The significance of the bacteria influence for the microalgae growth rate was analysed together using ANOVA in SPSS, then were followed by Tukey post-hoc analysis at $\mathrm{P} \leq 0.05$.

\section{RESULT AND DISCUSSION}

\section{A. Medium of Culture}

The quality of tofu industrial wastewater that was used as the culture medium was presented in Table 1. This wastewater was provided by taking the effluent of anaerobic treatment of tofu industrial wastewater. The wastewater was filtered with clean cloth filter before being stored in glass bottles. The wastewater was kept in the refrigerator under $4^{\circ} \mathrm{C}$ prior to be used in the following day. While the dissolved oxygen and temperature of the whole process showed the optimum condition for the growth, the $\mathrm{pH}$ of the medium showed a slightly higher than the optimum condition. Table 1 show that the concentration of ammonium and phosphate, which are two macro nutrients for the microalgae, was about $0.5 \mathrm{mg} / \mathrm{l}$ and $1.66 \mathrm{mg} / \mathrm{l}$ respectively. It is typical that the phosphorus concentration in the tofu 
processing wastewater is higher than that of the ammonium concentration [18]. The ammonium concentration in the wastewater is quite low compared to the ammonium concentration of municipal wastewater. Several papers have reported that a common ammonium concentration of municipal wastewater was about $30 \mathrm{mg} / \mathrm{l}[31,32]$. Chiu [33] reported that higher concentration of ammonium was found in the dairy raw wastewater. However they suggested that it was not suitable for being used to cultivate microalgae directly.

TABLE I

INITIAL WATER QUALITY OF THE GROWTH MEDIUM

\begin{tabular}{|l|c|}
\hline \multicolumn{1}{|c|}{ Component } & Concentration \\
\hline Ammonium $(\mathrm{mg} / \mathrm{l})$ & 0.5 \\
\hline Nitrate $(\mathrm{mg} / \mathrm{l})$ & 0.12 \\
\hline Phosphate $(\mathrm{mg} / \mathrm{l})$ & 1.66 \\
\hline $\mathrm{DO}(\mathrm{mg} / \mathrm{l})^{*}$ & $7.1-7.6$ \\
\hline $\mathrm{pH}^{*}$ & $8.1-8.9$ \\
\hline${\text { Temperature }\left({ }^{\circ} \mathrm{C}\right)^{*}}^{*}$ & $25.1-26.9$ \\
\hline
\end{tabular}

\section{B. Effect Of Azospirillum sp Concentration on the Chlorella Vulgaris Growth Rate}

As shown in Figure 1, all treatments show the growth of microalgae until they reached their peak concentration, followed by dead phase. The peak concentration of microalgae and the time to reach the peak point vary for each treatment. A dead phase that was following the peak point indicates that the medium undergo substrate or nutrient depletion for the microbial growth. Since the substrate $\left(\mathrm{CO}_{2}\right)$ is supplied continuously by aeration, the depletion of macronutrient seems to take the dominant role on the dead of the microalgae. Among all treatments, A10 is the first treatment to reach the peak concentration (in day 7) with about $5.56 \times 10^{7}$ cells/ $\mathrm{mL}$, followed by $\mathrm{A} 8$ and $\mathrm{A} 2$, which reached its peak concentration in the following day. The earliest decrease of the microalgae in A10 is due to the earliest shortage of the nutrients. The earliest depletion of nutrients in A10 might due to the existence of the highest population of microalgae and GBP (Figure 2) in the medium that had highest consumption rates of nutrients.

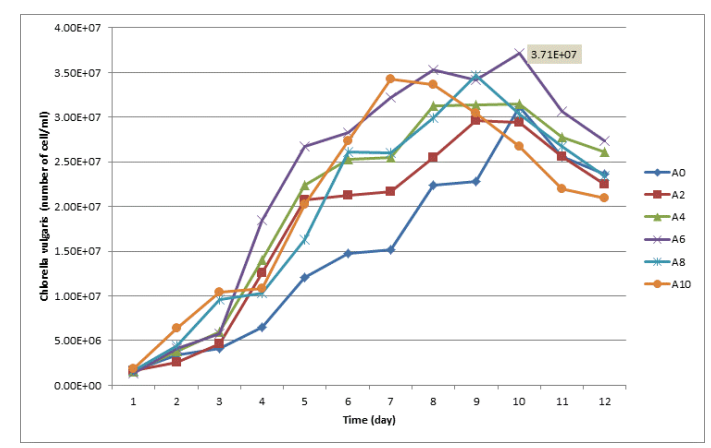

Fig.1 Population of Chlorella vulgaris

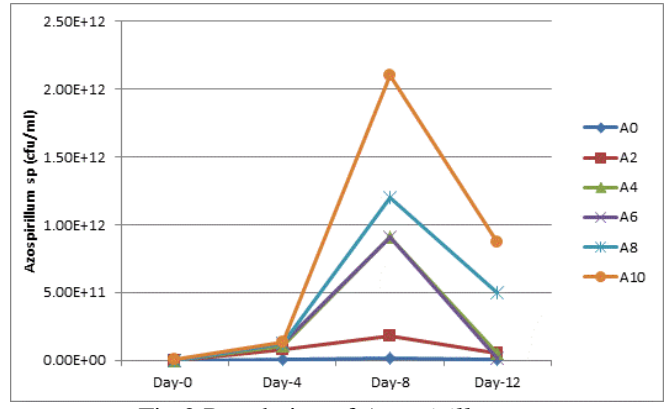

Fig.2 Population of Azospirillum $s p$

The highest concentration in peak point was achieved by A6 with its cell concentration of about $3.710^{7}$ in the tenth day. For treatment A2 and A4, it reached the peak point in day-8 and day-9, respectively. For A2 and A4, the peak point was continued by two and three days of stationary phase, respectively. This stationary phase was last until day10 , which was the time where $\mathrm{A} 0$ and $\mathrm{A} 6$ achieved the peak point. A longer time to reach peak point for several treatments might due to their lower microbes' concentration.

The result of the experiment also shows that Azospirillum $s p$ has significantly promoted the growth of the microalgae Chlorella vulgaris. Figure 1 illustrate that all bioreactors that had Azospirillum sp addition in it showed higher population of Chlorella vulgaris than that of without Azospirillum sp. While in the bioreactors that had no GPB in it shows its final population increase for about thirteen fold, a higher final population was demonstrated by the Chlorella $s p$ in the treatment with Azospirillum sp, i.e from 18 to 27 times higher as much as its initial population. The increase of the Azospirillum $s p$ also occurred in this experiment (Figure 2). Among all treatments, the highest population was achieved by A6 with $37.13 \times 10^{7}$ cells $/ \mathrm{ml}$, and it was achieved in the tenth day. This finding is higher than the result reported by Bashan et al [27] where co-cultured of microalgae and GBP was immobilized in alginate beads for ten days, which was only about 5 times higher than the initial population. This might due to in this experiment; the microalgae live freely in the wastewater compared to the immobilized microalgae. From the day-1 until the day-10, all the treatment shows an increase on the microalgae population, except for A8 and A10. The peak population for A8 and A10 occurred in the ninth and seventh day respectively, and then started to decline. This decrease might be because of the ammonium shortage in the ninth day (for A8) and seventh day (for A10), or even in several days before (Figure 4a). It could also be said that ammonium was the limiting factor for this culture.

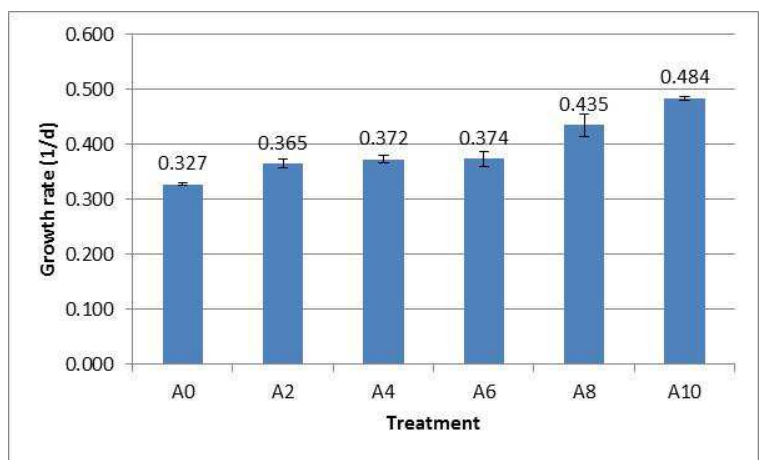

Fig.3 Average growth rate of microalgae 
By computing the experiment result using formula 1 , it shows that the highest average growth rate was achieved by A10 followed by A8, which were $0.484 \mathrm{~d}^{-1}$ and $0.435 \mathrm{~d}^{-1}$ respectively (Figure 3). Even though they achieved the highest growth rate, the highest peak population of microalgae among all treatments was achieved by A6. The rapid ammonium utilization rate by both microalgae and GPB in A10 and A8 might have caused they underwent higher rate but only in a shorter period due to nutrient shortage.

TABLE II

STATISTICAL ANALYSIS OF THE GROWTH RATE

\begin{tabular}{|l|r|r|r|r|r|}
\hline & & \multicolumn{4}{|c|}{ Subset for alpha $=.05$} \\
\cline { 3 - 6 } Treatment & $\mathrm{N}$ & 1 & 2 & \multicolumn{1}{c|}{3} & \multicolumn{1}{c|}{} \\
\hline A0 & 3 & .327467 & & & \\
A2 & 3 & & .364647 & & \\
A4 & 3 & & .372329 & & \\
A6 & 3 & & .373500 & & \\
A8 & 3 & & & .434527 & \\
A10 & 3 & & & & .483642 \\
Sig. & & 1.000 & .928 & 1.000 & 1.000 \\
\hline
\end{tabular}

The significance of the GPB concentration on the growth rate was analysed using one-way Anova and followed by Tukey post-hoc analysis (Table 2). In general, the result shows that GPB had significant impact on the growth rate of microalgae. By comparing the growth rate of A2, A4 and A6 descriptively, there was a slight difference on the growth rate of the microalgae among the treatments. However, there was no significant difference in the growth rate of those three treatments statistically. Treatment with initial concentration of GPB higher than $1.5 \times 10^{6} \mathrm{cfu} / \mathrm{ml}$ (A8 and A10) had significance difference compared to other treatments.

\section{Effect of Azospirillum sp on the Nutrient Removal of the Medium}

To analyse how the process could also performed nutrients removal, the water quality was measured every four day. The initial concentration of the nutrient was reported in Table 1. Except for A0, all the ammonium concentration was below $0.01 \mathrm{mg} / \mathrm{ml}$ in the fourth day (Figure 4A). In the day-8, no ammonium concentration was detected in all treatment. It was the reason why all the treatment experienced growth rate decrease after eight day. A complete removal of ammonium was also demonstrated by de-Bashan et al [28], when co-cultured of microalgae and GBP was applied into nutrient-containing wastewater. Less removal of ammonium was demonstrated when microalgae was employ alone in the semi continuous reactor [34] and [35]. A different condition occurred in the nitrate concentration that the final concentration was higher that its initial concentration in all treatment, but A8 and A10 where its concentrations were slightly lower than its initial concentration (Figure 4B). The rising of nitrate concentration was also reported by Gonzalez et al [34] when the wastewater was used as a medium for microalgae culture. The increase of the nitrate in an aerated treatment might be the result of nitrification when the ammonium was biologically converted into nitrate by the nitrifying bacteria. This typical conversion is occurred in aerobic section of suspended growth process for nitrogen removal.

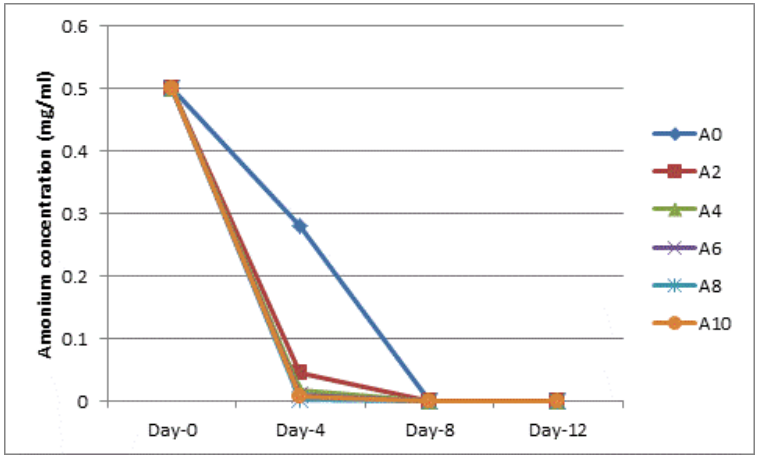

(a)

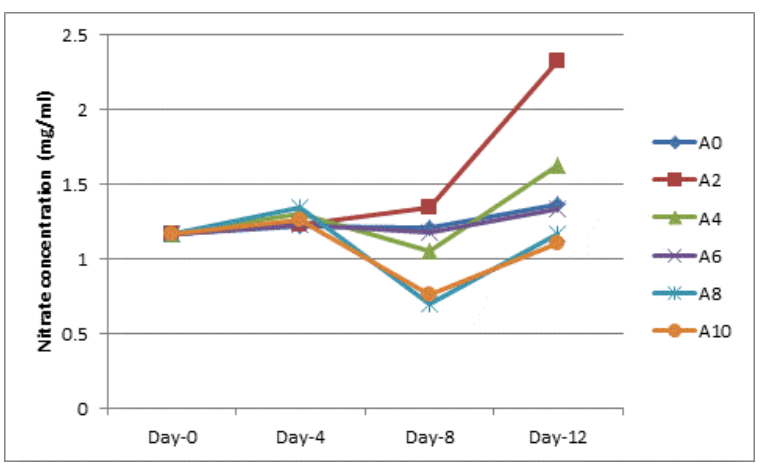

(b)

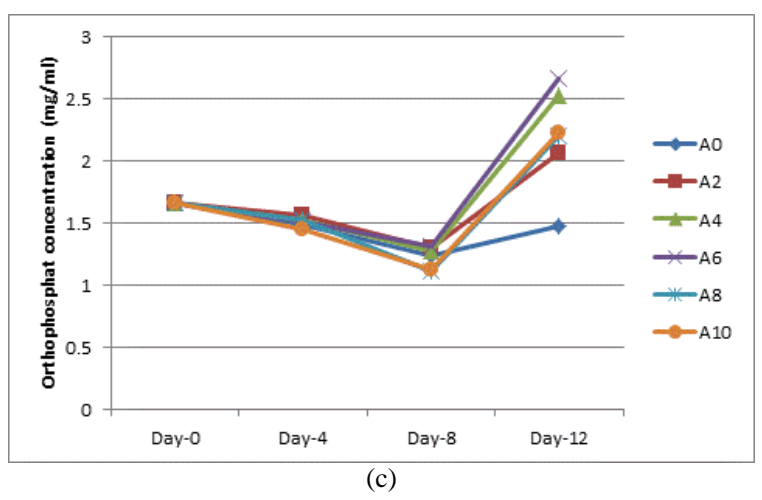

Fig.4 Nutrient concentration of the medium. (a) ammonium, (b) nitrate, (c) orthophosphate

In the first eight day, all the phosphate showed a removal, which is between $21 \%$ to $32 \%$. The highest 8 day-removal achieved by A10 (32\%) while the lowest removal achieved by A6 (21\%). A better removal (36\%) showed by de-Bashan [28] when the microalgae co-immobilized in alginate beds with Azospirillum brasilliensis, but lower removal when the microalgae was immobilised alone (19\%). The best phosphate removal $(85 \%)$ was reported when an advanced coupled treatment of attached microalgae biofilm and membrane bioreactor was applied for wastewater [36].

In this research, unexpected final concentration occurs in the final phosphate concentration. All the treatment show higher phosphate concentration than the initial. The increase of the phosphate concentration might have relation to the decay of the microalgae as well as the Azospirillum sp. Stopping the process before the decay phase of microalgae likely needs to be done to avoid the increase of phosphate due to the microalgae decay. 


\section{CONCLUSIONS}

This study demonstrated that GPB has significantly promoted the growth of microalgae. While in the lower GPB addition it did not show the significance of the GPB concentration in their growth rate, their significant influences were demonstrated in higher GPB concentration. Removal of ammonium was also demonstrated by the microalgae, either alone or co-cultured with GBP. Nitrate and phosphate concentration increased during the process. Since the nitrate and phosphate removal was not well performed by the process, an additional work has to be done to remove both nutrients.

\section{NOMENCLATURE}

$\begin{array}{lll}\mu & \text { specific growth rate } & \text { day }^{-1} \\ \mathrm{X}_{\max } & \begin{array}{l}\text { maximum cell concentration } \\ \text { cell } / \mathrm{mL}\end{array} \\ \mathrm{X}_{0} & \begin{array}{l}\text { initial cell concentration } \\ \text { cell } / \mathrm{mL}\end{array} \\ \mathrm{T}_{\max } & \begin{array}{l}\text { time when the cell reach its maximum } \\ \text { day-n } \mathrm{n}\end{array} \\ \mathrm{T}_{0} & \begin{array}{l}\text { concentration } \\ \text { initial time }\end{array} & \text { day-0 }\end{array}$

\section{REFERENCES}

[1] Li, Y., Mark, H., Wang, B., Wu, N., \& Lan, CQ. Effects of nitrogen sources on cell growth and lipid accumulation of green alga Neochloris oleoabundans. Applied Microbiology and Biotechnology, 2008. 81(4): p. 629-636.

[2] Rodolfi, L., Zittelli, G C., Bassi, N., Padovani, G., Biondi, N. Bonini, G., \& Tredici, M. R. Microalgae for oil: Strain selection, induction of lipid synthesis and outdoor mass cultivation in a low-cost photobioreactor. Biotechnology and Bioengineering, 2008. 102(1): p. 100-112.

[3] Yoo, C., Jun, S., Lee, J., Ahn, C., \& Oh, H. Selection of microalgae for lipid production under high levels carbon dioxide. Bioresource Technology, 2010. 101(1, Supplement): p. S71-S74.

[4] Dayananda, C., Sarada, R., Rani, M., Shamala, T. R., \& Ravishankar, G. A. Autotrophic cultivation of Botryococcus braunii for the production of hydrocarbons and exopolysaccharides in various media. Biomass and Bioenergy, 2007. 31(1): p. 87-93.

[5] Chisti, Y., Biodiesel from microalgae. Biotechnology Advances, 2007. 25(3): p. 294-306.

[6] Teresa, M.M., A.M. Antonio, and N.S. Caetano, Microalgae for Biodiesel Production and Other Applications: A Review. Renewable and Sustainable Energy Reviews, 2010. 14: p. 217-232.

[7] Park, J.B.K., R.J. Craggs, and A.N. Shilton, Wastewater treatment high rate algal ponds for biofuel production. Bioresource Technology, 2011. 102(1): p. 35-42.

[8] Abdelaziz, A.E.M., Leite, G. B., Belhaj, M. A, \& Hallenbeck, P. C. Screening microalgae native to Quebec for wastewater treatment and biodiesel production. Bioresource Technology, 2014. 157(0): p. 140148.

[9] Nugroho, W.A., Nurlaili, F.R., Hendrawan, Y., and Argo, B.D., Effect of Growth Promoting Bacteria on the Growth Rate and Lipid Content of Microalgae Chorella sp in Sludge Liquor of Anaerobic Digester of Dairy Manure. International Journal on Advanced Science, Engineering and Information Technology 2015. Vol 5.

[10] Pittman, J.K., A.P. Dean, and O. Osundeko, The potential of sustainable algal biofuel production using wastewater resources. Bioresource Technology, 2011. 102(1): p. 17-25.

[11] Matamoros, V., Gutierrez, R., Ferrer, I., Garcia, J., and Bayona, J.M. Capability of microalgae-based wastewater treatment systems to remove emerging organic contaminants: A pilot-scale study. Journal of Hazardous Materials, 2015. 288: p. 34-42.

[12] Passos, F., Felix, L., Rocha, H., Pereira, J.O., de Aquino, S. Reuse of microalgae grown in full-scale wastewater treatment ponds: Thermochemical pretreatment and biogas production. Bioresource Technology, 2016. 209: p. 305-312.

[13] Li, Y., Chen, Y., Chen, P., Min, M., Zhou, W., Martinez, B., Zhu, J., \& Ruan, R. Characterization of a microalga Chlorella sp. well adapted to highly concentrated municipal wastewater for nutrient removal and biodiesel production. Bioresource Technology, 2011. 102(8): p. 5138-5144.

[14] Yang, L., Tan, X., Li, D., Chu, H., Zhou, X., Zhang, Y., and Yu, H. Nutrients removal and lipids production by Chlorella pyrenoidosa cultivation using anaerobic digested starch wastewater and alcohol wastewater. Bioresource Technology, 2015. 181: p. 54-61.

[15] Caporgno, M.P., Taleb, A., Olkiewicz, M., Font, J., Pruvost, J., Legrand, J., and Bengoa, C. Microalgae cultivation in urban wastewater: Nutrient removal and biomass production for biodiesel and methane. Algal Research, 2015. 10: p. 232-239.

[16] Tagawa, T., Takahashi, H., Sekiguchi, Y., Ohashi, A., \& Harada, H. Pilot-plant study on anaerobic treatment of a lipid- and protein-rich food industrial wastewater by a thermophilic multi-staged UASB reactor Water Science \& Technology, 2002. Vol 45(10): p. 225-230.

[17] Ramsay, I. and P. Pullammanappallil, Protein degradation during anaerobic wastewater treatment: derivation of stoichiometry. Biodegradation, 2001. 12(4): p. 247-256.

[18] Nugroho, W.A., Hermanto, B., Lutfi, M., \& Fakhri, M. Phosphorus Removal of Tofu Processing Wastewater in Recirculated Raceway Pond Bioreactor by Chlorella vulgaris. Nature Environment \& Pollution Technology, 2014. 13(4): p. 859-863.

[19] Xin, L., Hong-ying, H., Ke, G., \& Ying-xue, S. Effects of different nitrogen and phosphorus concentrations on the growth, nutrient uptake, and lipid accumulation of a freshwater microalga Scenedesmus sp. Bioresource Technology, 2010. 101(14): p. 54945500 .

[20] Posadas, E., Morales, M., Gomez, C., Acien, F.G., and Munoz, R. Influence of $\mathrm{pH}$ and $\mathrm{CO} 2$ source on the performance of microalgaebased secondary domestic wastewater treatment in outdoors pilot raceways. Chemical Engineering Journal, 2015. 265: p. 239-248.

[21] White, P., Kalff, J., Rasmussen, J. B., \& Gasol, J. M. The effect of temperature and algal biomass on bacterial production and specific growth rate in freshwater and marine habitats. Microbial Ecology, 1991. 21(1): p. 99-118.

[22] He, Q., Yang, H., Xu, L., Xia, L., and Hu, C. Sufficient utilization of natural fluctuating light intensity is an effective approach of promoting lipid productivity in oleaginous microalgal cultivation outdoors. Bioresource Technology, 2015. 180: p. 79-87.

[23] Yarnold, J., I.L. Ross, and B. Hankamer, Photoacclimation and productivity of Chlamydomonas reinhardtii grown in fluctuating light regimes which simulate outdoor algal culture conditions. Algal Research, 2016. 13: p. 182-194.

[24] De-Bashan, L.E., H. Antoun, and Y. Bashan, Cultivation factors and population size control the uptake of nitrogen by the microalgae Chlorella vulgaris when interacting with the microalgae growthpromoting bacterium Azospirillum brasilense. FEMS Microbiology Ecology, 2005. 54(2): p. 197-203.

[25] Wang, L., Min, M., Li, Y., Chen, P., Chen, Y., Liu, Y., Wang, Y., \& Ruan, R. Cultivation of Green Algae Chlorella sp. in Different Wastewaters from Municipal Wastewater Treatment Plant. Applied Biochemistry and Biotechnology, 2010. 162(4): p. 1174-1186.

[26] Zhou, W., Li, Y., Min, M., Hu, B., Chen, P., \& Ruan, R. Local bioprospecting for high-lipid producing microalgal strains to be grown on concentrated municipal wastewater for biofuel production. Bioresource Technology, 2011. 102(13): p. 6909-6919.

[27] de-Bashan, L.E. and Y. Bashan, Joint Immobilization of Plant Growth-Promoting Bacteria and Green Microalgae in Alginate Beads as an Experimental Model for Studying Plant-Bacterium Interactions. Applied and Environmental Microbiology, 2008. 74(21): p. $6797-$ 6802.

[28] de-Bashan, L.E., Hernandez, J., Morey, T., \& Bashan, Y. Microalgae growth-promoting bacteria as helper for microalgae: a novel approach for removing ammonium and phosphorus from municipal wastewater. Water Research, 2004. 38(2): p. 466-474.

[29] Eckert, B., Weber, O. B., Kirchhof, G., Halbritter, A., Stoffels, M., \& Hartmann, A. Azospirillum doebereinerae sp. nov., a nitrogen-fixing bacterium associated with the C4-grass Miscanthus. International Journal of Systematic and Evolutionary Microbiology, 2001. 51(1): p. $17-26$.

[30] Akbari, G.A., Arab, S. M., Alikhani, H.A., Allahdadi, I., \& Arzanesh, M.H. Isolation and Selection of Indigenous Azospirillumspp. and the IAA of Superior Strains Effects on Wheat Roots. World Journal of Agricultural Sciences 2007. 3( (4)): p. 523-529.

[31] Monclus, H., Sipma, J., Ferrero, G., Comas, J., \& Rodriguez-Roda, I. Optimization of biological nutrient removal in a pilot plant UCTMBR treating municipal wastewater during start-up. Desalination, 2010. 250(2): p. 592-597. 
[32] Woertz, I., Feffer, A., Lundquist, T., and Nelson, Y. Algae Grown on Dairy and Municipal Wastewater for Simultaneous Nutrient Removal and Lipid Production for Biofuel Feedstock. Journal of Environmental Engineering, 2009. 135(11): p. 1115-1122.

[33] Chiu, S.-Y., Kao, C., Chen, T., Chang, Y., Kuo, C., and Lin, C. Cultivation of microalgal Chlorella for biomass and lipid production using wastewater as nutrient resource. Bioresource Technology, 2015. 184: p. 179-189.

[34] Gonzalez, L.E., R.O. Canizares, and S. Baena, Efficiency of ammonia and phosphorus removal from a colombian agroindustrial wastewater by the microalgae Chlorella vulgaris and Scenedesmus dimorphus. Bioresource Technology, 1997. 60(3): p. 259-262.

[35] de-Bashan, L.E., Moreno, M., Hernandez, J.P., and Bashan, Y. Removal of ammonium and phosphorus ions from synthetic wastewater by the microalgae Chlorella vulgaris coimmobilized in alginate beads with the microalgae growth-promoting bacterium Azospirillum brasilense. Water Research, 2002. 36(12): p. 2941-2948.

[36] Gao, F., Yang, Z., Li, C., Zeng, G., Ma, D., and Zhou, L. A novel algal biofilm membrane photobioreactor for attached microalgae growth and nutrients removal from secondary effluent. Bioresource Technology, 2015. 179: p. 8-12. 